\title{
KESEHATAN MENTAL PADA AKTIVIS JAMA'AH TABLIG JAKARTA SELATAN PERSPEKTIF POSITIVE MENTAL HEALTH
}

\author{
Ahmad Rusydi \\ Program Pascasarjana UIN Syarif Hidayatullah Jakarta \\ Email: Ahmad_Rusydi@ymail.com
}

\begin{abstract}
Not all optimistic about the results of the study of religion. Several studies assume that religion is bad for human psychological. This study would like to refute the studies. This research proves that people who follow religious activities tend to have higher mental health. The main source of this study is the Jamat activists Tabliq South Jakarta by taking a sample of 130 people. The study was conducted by analyzing the frequency distribution. Researchers also complements the data of this study with interviews regarding religious activity and everyday respondents.
\end{abstract}

Keywords: Religion, Islam, Mental Health, Jamat-Tabliq

\begin{abstract}
Abstrak
Tidak semua hasil penelitian optimis terhadap agama. Beberapa hasil penelitian menganggap bahwa agama berdampak buruk bagi psikologis manusia. Penelitian ini ingin membatah penelitian-penelitian tersebut. penelitian ini membuktikan bahwa orang yang mengikuti kegiatan keagamaan cenderung memiliki kesehatan mental yang tinggi. Sumber utama penelitian ini adalah Aktivis Jama'ah Tablig Jakarta Selatan dengan mengambil sampel sebanyak 130 orang. Penelitian dilakukan dengan melakukan analisis distribusi frekuensi. Peneliti juga melengkapi data penelitian ini dengan wawancara yang berkenaan dengan kegiatan agama dan keseharian responden.
\end{abstract}

Kata Kunci: Agama, Islam, Kesehatan Mental, Jama'ah Tablig

$\mathrm{K}$ ondisi kesehatan mental di zaman ini sangat memprihatinkan. Data WHO tahun 2002 menyebutkan bahwa 150 juta orang menderita depresi, satu juta orang melakukan bunuh diri tiap tahunnya, 25 juta orang menderita schizofrenia, 38 juta orang menderita epilepsi, dan 90 juta orang melakukan penyalahgunaan obat dan alkohol. WHO juga memprediksikan bahwa pada tahun 2020 jumlah penderita gangguan mental akan bertambah menjadi $15 \%$ dari penderita semua gangguan penyakit, sebelumnya $13 \%$ pada tahun 2003 , dan $11 \%$ pada tahun 1990 .

Jika melihat anggapan dunia tentang kemajauan psikologi, namun fakta menunjukkan sebaliknya. Kemajuan di bidang psikologi harusnya diikuti dengan penurunan angka gangguan mental, namun itu tidak terjadi. Tentu fakta ini seharusnya menjadi permasalahan besar. Ada apa dengan psikologi saat ini? Tentu saja psikologi saat ini sangat berbeda dengan psikologi di abad pertengahan sebelumnya. Psikologi saat ini berorientasi fisik, mengingkari konsepkonsep jiwa yang sangat metafisik dan agamis. Contohnya saja Freud yang menjelaskan bahwa Tuhan hanya sekedar ilusi. Watson menjelaskan bahwa psikologi tidak boleh mempelajari yang tidak bisa diamati. Adapun ajaran agama sangat banyak memuat tentang eksistensi non fisik, seperti ruh, hati, jiwa, dan akhirat.

Kondisi ini sangat relevan dengan berkembangnya paham sekuler dan ateis yang mewabah pada manusia modern saat ini. Psikologi berkembang mengikuti dasar paham sekuler sehingga menyingkirkan 
ajaran agama dalam mengkaji manusia. Bahkan beberapa pendapat menjelaskan bahwa justru agama menjadi penyebab gangguan mental. Exline dan Rose menjelaskan bahwa agama dapat memicu ekspresi psikopatologis. Wilson mengatakan bahwa agama dapat menyebabkan gejala manik, delusi, dan kecemasan. Mitchel dan Romans menjelaskan bahwa dari 147 pasien gangguan bipolar, $78 \%$ di antaranya memiliki keagamaan yang tinggi dan $81,5 \%$ melakukan ibadah secara sering (Palaoutzian \& Park, 2005)

Namun, mana mungkin agama yang mengajarkan kebaikan, memaafkan, berserah diri pada Tuhan, membantu orang lain, dan ajaran-ajaran baik itu membawa dampak buruk. Inilah dasar dari beberapa penelitian yang ingin menunjukkan bahwa agama akan membawa pengaruh baik bagi psikologis manusia. Bahkan kalanganan agamawan sangat meyakini bahwa hanya agama yang dapat membawa kebahagiaan.

Kaczorowski (1990) menjelaskan bahwa semakin tinggi keagamaan, maka akan semakin rendah kecemasan. Davis, Kerr, dan Kurpius (2003) menjelaskan bahwa semakin tinggi kebaikan beragama dan kebaikan spiritual maka akan semakin rendah kecemasan. Boscalgia, Clarke, Jobling, dan Quinn (2005) menjelaskan bahwa rendahnya spiritual akan berdampak pada depresi.

Penelitian ini ingin membuktikan hal yang serupa, bahwa mengikuti komunitas agama, melakukan aktivitas agama, dan mengamalkan ajaran agama tidak akan berdampak pada gangguan mental. Secara terbuka peneliti mengatakan bahwa penelitian ini bersumber dari data lapangan yang pernah didapat peneliti pada penelitian sebelumnya, yaitu penelitian yang berjudul

Religiositas dan Kesehatan Mental pada Aktivis Jama'ah Tablig Jakarta Selatan yang telah diterbitkan oleh Youth Progressive Muslim, Ciputat. Namun pada artikel kali ini berbeda. Peneliti akan meninjau lebih dalam lagi dan lebih fokus lagi mengenai kesehatan mental pada responden dan dengan perspektif yang berbeda pula yaitu perspektif positive mental health yang dikembangkan oleh Sarah Stewart Brown. Peneliti juga akan mewarnai artikel ini dengan pendekatan yang lebih religius.

\section{METODE PENELITIAN}

\section{Subjek}

Sumber utama penelitian ini adalah Aktivis Jama'ah Tablig Jakarta Selatan dengan mengambil sampel sebanyak 130 orang.

\section{Pendekatan Penelitian}

Penelitian ini menggunakan pendekatan positive mental health yang diajukan oleh Sarah Stewart-Brown,. Hu, Y.J., Twigg, L. Weich, S. (2007). Peneliti menggunakan pendekatan ini karena kebanyakan konsep kesehatan mental hanya melihat tinggi rendahnya gejala atau simptom gangguan mental. Jika gejala dan simptomnya tidak ada, maka subjek dikatakan sehat mental dan sebaliknya. Adapun pendekatan ini memandang kesehatan mental secara positif. Untuk melihat bagaimana konsep positive mental health dapat dilihat pada bagan di bawah ini.

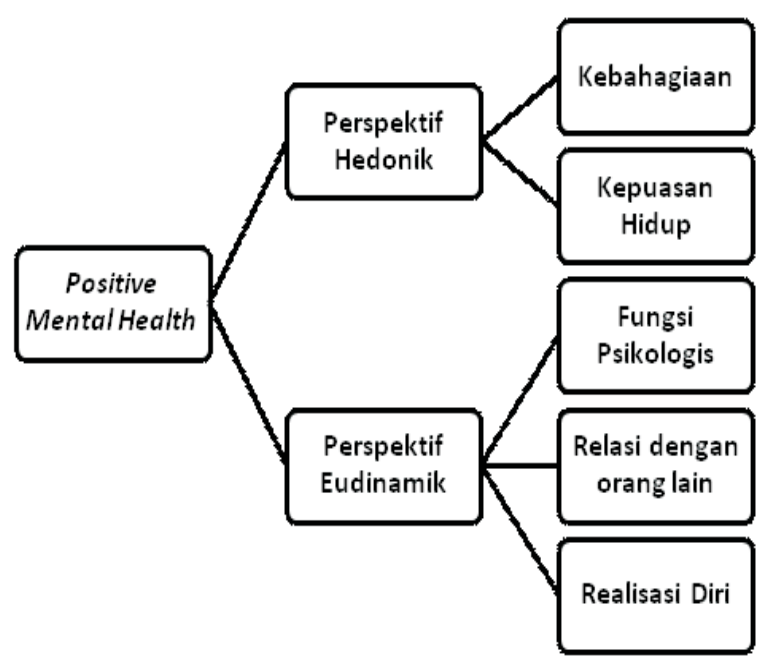

Bagan 1. Kerangka Konsep Positive Mental Health 
Berdasar bagan di atas sangat jelas terlihat bahwa kesehatan mental bisa dipelajari melalui indikator-indikator yang positif bukan simptom. Seperti kebahagiaan, kepuasan hidup, fungsi psikologis, relasi dengan orang lain, dan realisasi diri. Perspektif hedonik adalah kesehatan mental yang bersifat subjektif. Kesehatan mental hedonik muncul karena perasaan dalam diri. Adapun perspektif eudinamik adalah kesehatan mental yang menunjukkan baiknya fungsi mental dalam kehidupan sehari-hari, seperti mampu merealisasi diri dan mampu berhubungan baik dengan orang lain.

\section{Alat Ukur}

Dari teori ini, Stewart-Brown sudah membuat alat ukur kesehatan mental. peneliti juga melakukan adaptasi alat ukur ini dan melakukan uji validitas dan reliabilitas pada alat ukur ini. Uji validitas dilakukan dengan menggunakan teknik item-total correlation. Adapun untuk uji reliabilitas menggunakan teknik rumus CronbachAlpha. Berikut hasil uji alat ukur tersebut.

Tabel. Hasil Uji Validitas

\begin{tabular}{|c|c|}
\hline Aspek dan Aitem & $\begin{array}{l}\text { Koefesien } \\
\text { Korelasi }\end{array}$ \\
\hline $\begin{array}{l}\text { Hedonik } \\
\text { 1. Happiness (Kebahagiaan) }\end{array}$ & \\
\hline Saya merasa ceria & $0,482 * *$ \\
\hline $\begin{array}{l}\text { 2. Life Satisfaction (Kepuasan Hidup) } \\
\text { Saya merasa diri saya berguna bagi orang lain } \\
\text { Saya merasa dicintai }\end{array}$ & $\begin{array}{l}0,651 * * \\
0,433 * *\end{array}$ \\
\hline $\begin{array}{l}\text { Eudinamik } \\
\text { 1. Psychological Functioning } \\
\text { (Keberfungsian Psikologis) }\end{array}$ & $0,480 * *$ \\
\hline $\begin{array}{l}\text { Saya merasa rileks } \\
\text { Saya memiliki kekuatan untuk bekerja keras } \\
\text { Saya dapat menyelesaikan masalah dengan baik } \\
\text { Saya dapat berfikir dengan jernih } \\
\text { Saya merasa diri saya sehat }\end{array}$ & $\begin{array}{l}0,612 * * \\
0,523 * * \\
0,499 * * \\
0,294 * * \\
0,393 * *\end{array}$ \\
\hline $\begin{array}{l}\text { Saya tertarik dengan sesuatu yang baru } \\
\text { 2. Good Relationship with Others } \\
\text { (Hubungan baik dengan orang lain) }\end{array}$ & $\begin{array}{l}0,436^{* *} \\
0,553 * *\end{array}$ \\
\hline Saya peduli dengan kehidupan orang lain & \\
\hline $\begin{array}{l}\text { Saya merasa dekat dengan orang lain } \\
\text { 3. Self Realisation (Realisasi Diri) } \\
\text { Saya optimis dengan masa depan saya } \\
\text { Saya merasa percaya diri } \\
\text { Saya mampu mewujudkan ide dan pikiran saya }\end{array}$ & $\begin{array}{l}0,502 * * \\
0,462 * * \\
0,542 * *\end{array}$ \\
\hline
\end{tabular}

** Item valid pada taraf signifikansi 1\%.

*Item valid pada taraf signifikansi 5\%

Berdasarkan perhitungan di atas, dapat diketahui bahwa semua aitem valid pada taraf signifkansi 1\%. Harga minimal validitas aitem yang berdasarkan $r$ tabel pada $\mathrm{n}=125$ pada taraf signifikansi $5 \%$ adalah 0,176. Adapun hasil analisis CronbachAlpha menunjukkan skor 0,847. Angka ini cukup tinggi karena mendekati 1.

Selanjutnya peneliti melakukan analisis berdasarkan distribusi untuk melihat berapa responden yang berada pada tingkat kesehatan mental sangat rendah, rendah, sedang, tinggi, atau sangat tinggi. Kategorisasi dilakukan dengan melihat jarak antara skor minimum 14 dan skor maksimum 70, kemudian peneliti membuat lima kategori tersebut (Stewart-Brown, $\mathrm{Hu}$, Twigg, Weich, 2007). Dalam buku pedoman tersebut juga dijelaskan bahwa pada saat pembuatan alat tes WEMWBS dengan menggunakan puluhan ribu sampel ternyata ditemukan rata-rata skor sebesar 50 sampai 51, sementara pada Jama'ah Tablig rata-rata skor mencapai 56, artinya rata-rata kesehatan mental pada aktivis Jama'ah Tablig lebih tinggi 6 poin dari pada individu pada umumnya. Dalam penelitian ini, peneliti juga melengkapi data hasil wawancara dengan beberapa responden untuk mengetahui bagaimana kegiatan keagamaan mereka dan bagaimana keseharian mereka serta bagaimana agama yang mereka pahami berperan dalam kehidupan keseharian mereka.

\section{Teknik Analisis Data}

Penelitian dilakukan dengan melakukan analisis distribusi frekuensi.

\section{HASIL PENELITIAN DAN PEMBAHASAN}

\section{Kesehatan Mental Secara Umum \\ Grafik berikut menjelaskan bagaimana kesehatan mental secara umum pada aktivis Jama'ah Tablig Jakarta Selatan.}


Grafik1. Kondisi Kesehatan Mental pada Aktivis Jama'ah Tabligh

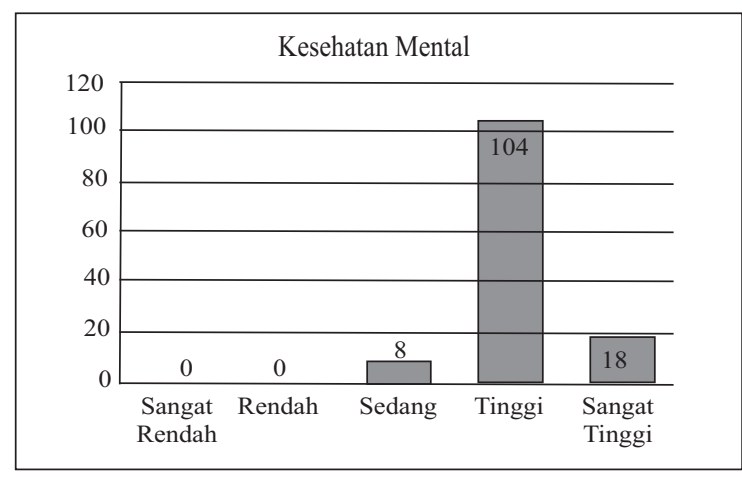

Dari tabel dan grafik di atas, dapat diketahui bahwa kebanyakan tingkat kesehatan mental Aktivis Jama'ah Tablig berada pada kategori kesehatan mental tinggi, dengan jumlah sebanyak 104 orang $(80 \%)$, dan sebanyak 18 orang berada pada kategori kesehatan mental sangat tinggi dengan 18 orang $(13,85 \%)$ dan ada 8 orang yang berada pada kategori kesehatan mental sedang $(6,15 \%)$. Diketahui tidak ada yang berada pada kategori rendah dan sangat rendah, artinya tidak ada anggota responden yang mengalami sakit mental, atau kesehatan mental yang rendah.

Data ini telah membuktikan bahwa mengikuti aktivitas kelompok keagaman justru memberikan dampak yang baik pada kesehatan mental. Tidak terbukti sedikit pun bahwa agama berpengaruh pada gangguan mental. Tidak ada satu pun responden yang menunjukkan kesehatan mental yang rendah ataupun sangat rendah. Bahkan kebanyakan mereka berada pada kesehatan mental yang tinggi.

Tidak perlu lagi disebutkan teoriteori yang mendukung fakta ini. Hal ini menunjukkan bahwa agama akan memberikan ketenteraman jiwa pada pemeluknya. Ajaran-ajaran agama yang baik mengajarkan seperti berserah pada Tuhan, berbuat baik pada orang lain, bersabar, dan ajaran-ajaran agama lain tentunya membawa kebaikan jiwa dan kesehatan psikologis.

Mengikuti ajaran agama dengan baik dan sempurna dapat disebut dengan istilah bertakwa. Agama sangat penting dalam menunjang kehidupan seseorang karena agama memuat petunjuk-petunjuk kebenaran yang sangat aplikatif. Menjadi individu yang beriman dan bertakwa tentunya akan mendatangkan kesejahteraan.

Bahkan hal semacam ini telah dijelaskan dalam Al-Qur'an bahwa barang siapa yang beriman akan mendapatkan keberkahan dan kenikmatan baik yang bersifat fisik maupun psikis. Hal ini sebagaimana dijelaskan dalam surat al-A'raf ayat 96 . Allah berfirman:

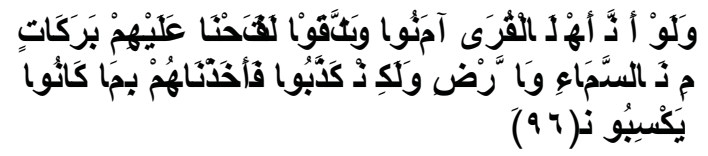

"Jikalau sekiranya penduduk negeri-negeri beriman dan bertakwa, pastilah Kami akan melimpahkan kepada mereka berkah dari langit dan bumi, tetapi mereka mendustakan (ayat-ayat Kami) itu, maka Kami siksa mereka disebabkan perbuatannya."

Ayat di atas menjelaskan bahwa tingkat kedekatan, keimanan, dan ketakwaan diri kepada Tuhan akan berpengaruh terhadap kesejahteraan psikis (dari langit) maupun kesejahteraan fisik (dari bumi). Maka kualitas psikologis yang baik sangat relevan jika dibentuk melalui agama, karena agama menjelaskan bagaimana pembentukan jiwa yang baik. Bagaimana menghilangkan gejala-gejala buruk atau simtom patologi dan bagaimana cara membentuk dan mengembangkan sifat-sifat baik.

Al-Ghazali (t.t.) menjelaskan bahwa meningkatkan tingkatan dan kualitas jiwa harus dilakukan dengan cara pengosongan diri (takhally) dari sifat-sifat buruk kemudian mengisi jiwa (tahally) dengan sifat-sifat baik. Untuk mengetahui sifat yang buruk, apa bahayanya, dan apa dampaknya, agama sudah sangat menjelaskan secara komprehensif. Begitu pula untuk mengetahui sifat yang baik, bagaimana meraihnya, dan apa manfaatnya, juga sangat sempurna dijelaskan oleh agama.

Banyak teori yang mengatakan bahwa hal yang paling berpengaruh terhadap kesehatan mental adalah faktor ekonomi sebagaimana penelitian yang dilakukan oleh Vogelsang (1999), Bilsker (2006), Albernaz (2011), serta Saraceno dan Barbui (1997). 
Namun hasil penelitian ini menunjukkan sebaliknya. Berdasarkan observasi dan wawancara peneliti menemukan bahwa jumlah aktivis yang berada pada tingkat ekonomi rendah cukup banyak. Namun, tidak ada di antara mereka yang mengalami masalah mental yang serius. Padahal tekanan kemiskinan merupakan faktor penyebab depresi yang cukup dominan sebagaimana penelitian-penelitian yang telah dilakukan.

Agama mampu memberikan jalan keluar ketika manusia berada dalam tekanan kemiskinan. Berdasarkan wawancara yang dilakukan oleh peneliti, sekalipun mereka berada dalam kesulitan ekonomi, namun mereka merasakan itu semua bukan sebagai penderitaan. Mereka lebih memikirkan usaha dakwah dibandingkan usaha mengumpulkan kekayaan. Sebagaimana kegiatan utama mereka yaitu melakukan khuruj, tentunya ini dapat mengganggu aktivitas ekonomi dan pekerjaan mereka. Namun mereka tidak mempedulikannya. Kebanyakan mereka berwirausaha agar bisa terbebas dari keterikatan dunia kerja. Kegiatan agama inilah yang menjadi sumber terpeliharanya kesehatan mental. Aktivitas agama menyediakan dukungan sosial, coping agama, dan sebagai wadah untuk merealisasikan diri dan potensi psikologis.

\section{Tingkat Kebahagiaan}

Kebahagiaan dapat dicapai oleh siapapun selama dia bisa menyikapi hidupnya dengan baik. Agama banyak mengajarkan tentang menyikapi hidup. Ajaran itu tentunya akan berdampak baik bagi psikologis khususnya pada kebahagiaan seseorang. Hal itu dibuktikan pada grafik di bawah ini mengenai tingkat kebahagiaan pada Aktivis Jama'ah Tablig Jakarta Selatan.

Grafik 2. Tingkat Kebahagiaan.

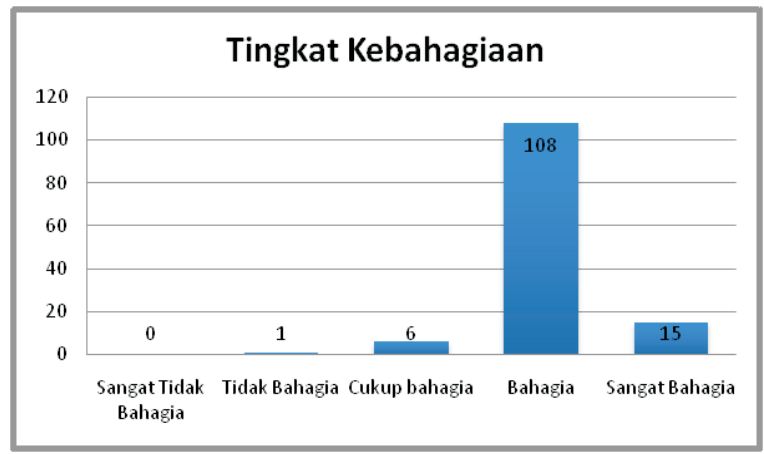

Dari grafik di atas, dapat diketahui bahwasanya 108 orang responden merasa bahagia $(83,1 \%), 15$ orang merasa sangat bahagia $(11,54 \%)$, dan 6 orang merasa cukup bahagia $(4,6 \%)$, satu orang merasa tidak bahagia $(0,8 \%)$, dan tidak ada responden yang merasa sangat tidak bahagia. Dari data ini tentu saja dapat diketahui bahwa mereka kebanyakan merasa bahagia dengan hidupnya.

Bahagia merupakan indikasi dari jiwa yang sehat. Kebahagiaan tidak hanya bersifat fisik (pleasure), namun yang terpenting adalah psikis. Kajian tentang kebahagiaan telah menjadi kajian panjang dari sejak dahulu. Bahkan banyak yang mengatakan bahwa tujuan hidup manusia adalah untuk mencapai kebahagaiaan. Plato mengatakan bahwa kebahagiaan akan tercapai bila manusia telah sampai ke kerajaan ide. Aristoteles mengatakan bahwa kebahagiaan akan tercapai bila manusia mengaktualkan potensi utamanya yaitu potensi intelektual. Miskawaih mengatakan bahwa kebahagiaan akan tercapai apabila manusia memiliki akhlak yang baik, selama manusia memiliki akhlak buruk, maka hidupnya akan menderita. Kalangan Sufisme mengatakan bahwa kebahagiaan akan tercapai bila manusia mendekatkan diri pada Tuhan, selama manusia masih jauh pada Tuhan, maka hidupnya akan menderita. Ikhwan Al-Saffa mengatakan bahwa manusia yang membiasakan diri dengan akhirat akan bahagia di dunia dan akhirat, sementara manusia yang membiasakan diri dengan dunia akan selalu terkurung menderita baik di dunia apalagi di akhirat. Abraham Maslow mengatakan bahwa kebahagiaan akan tercapai bila manusia mampu memenuhi hierarki kebutuhannya sampai tingkat aktualisasi diri.

Agama mengajarkan manusia tentang alam akhirat (alam ide). Agama juga mengajarkan tentang kewajiban menuntut ilmu (memenuhi kebutuhan intelektual). Agama mengajarkan berakhlak baik. Agama mengajarkan manusia untuk senantiasa mendekatkan diri pada Tuhan. Agama mengajarkan untuk berhati-hati pada dunia dan menyiapkan bekal kehidupan hari akhir. Agama juga mengajarkan manusia untuk 
mengaktualisasikan diri dengan memberi manfaat kepada semesta alam. Oleh karena itu, tidak heran apabila agama sangat relevan dengan tercapainya kebahagiaan.

Seligman (2005) mengatakan bahwa orang yang bahagia ditandai dengan tiga hal, yaitu sehat secara fisik (the pleasent life), kebermanfaatan hidup bagi yang lain (enggaged life), dan hidup yang bermakna (the meaningfull life). Agama mengajarkan pada manusia untuk memelihara tubuh, bermanfaat bagi orang lain, dan agama juga telah memberikan hakikat dan tujuan hidup manusia.

Agama memerintahkan manusia memelihara tubuh. Memberinya dengan makanan yang halal dan baik. Begitu banyak kajian agama mengenai perawatan tubuh, seperti bab tentang makanan halal dan baik, bab tentang bersuci, bab tentang berlatih kuda, memanah, berenang, dan sebagainya. Semua itu diajarkan dalam agama karena manusia membutuhkan tubuh untuk mencapai tujuannya. Al-Ghazali (t.t.) mengatakan bahwa manusia ibarat kereta kuda yang harus mencapai tujuannya yaitu menuju Tuhan. Kabin kereta ibarat tubuh. Jika kabin itu rusak, manusia tidak akan bisa mencapai Tuhan. Jalaludin Rumi mengatakan bahwa tujuan hidup manusia adalah mendaki bukit tinggi menuju Tuhan. Manusia tidak akan bisa mendakinya jika kaki dan tangannya patah.

Berdasarkan observasi peneliti ketika mengikuti kegiatan mereka, nampaknya mereka sangat mementingkan kesehatan tubuh. Dalam kegiatan khuruj mereka memiliki jadwal makan yang teratur. Bahkan ada jadwal tidur yang sangat teratur. Makanan yang dimakan dalam aktivitas mereka juga makanan yang cukup bergizi seperti ikan dan sebagainya. Bahkan salah satu minuman favorit mereka adalah susu yang dicampur dengan teh. Semua ini bertujuan agar mendukung kesehatan tubuh yang harus bekerja keras selama berbulanbulan untuk melakukan usaha dakwah.

Agama juga memerintahkan manusia untuk mengisi hidupnya dengan memberikan manfaat (engaged life). Bahkan Allah mengutus Nabi Muhammad dan agama Islam tidak lain untuk memberi rahmat bagi semesta alam. Islam menganggap bahwa orang yang paling baik adalah yang paling bermanfaat, yang mengajarkan Al-Qur'an pada orang lain, dan sebagainya. Bahkan agama mengajarkan manusia untuk memakmurkan bumi seperti menanam biji kurma sekalipun besok hari kiamat. Agama memberikan keutamaan pada orang yang memberi minum seekor anjing. Semua ajaran-ajaran tersebut menunjukkan bahwa agama Islam adalah agama yang penuh dengan manfaat kepada seluruh manusia, bahkan hewan, tumbuhan, batuan, dan seluruh alam.

Aktivis Jama'ah Tablig sangat yakin bahwa melakukan usaha dakwah, mengajak manusia untuk ke masjid, beribadah, bahkan mengikuti gerakan mereka, adalah usaha yang dijanjikan Allah surga. Menurut mereka, manusia tidak bisa memberikan hidayah pada orang lain karena hanya Allah yang berhak memberikan hidayah. Namun manusia bisa menjadi media tersampainya hidayah Allah kepada seseorang. Maka manusia yang bermanfaat bagi mereka adalah yang bisa menjadi media hidayah (mereka menyebutnya asbab/sebab hidayah) bagi orang lain. Mereka tidak segan-segan untuk menjelajahi daerah-daerah terpencil hanya untuk memberi manfaat (sebab hidayah) bagi orang lain.

Bahkan dalam usaha mereka, tidak jarang mereka mendapat penolakan, perlawanan, bahkan kekerasan yang seharusnya membuat mereka tidak bahagia (unhappy). Namun mereka menjalani itu semua dengan nyaman, karena agama mengajarkan bagaimana tantangan dakwah yang dialami oleh para Nabi dan para sahabat, dan itu sudah menjadi doktrin mereka dalam ta'lim mereka sehari-hari bahkan tidak jarang di antara mereka bangga dengan pengalaman-pengalam semacam itu. Upaya dakwah yang mereka lakukan juga harus meninggalkan keluarga, namun mereka bisa menikmati kegiatan ini. Diener (2009) mengatakan bahwa individu yang bahagia selalu menjalani hidupnya dengan nikmat (joy) dan jarang merasa sedih, kecewa, marah, takut, dan emosi buruk lain. Kebahagiaan sangat tergantung dengan pikiran dan perasaan yang positif. 


\section{Tingkat Kepuasan Hidup}

Kepuasan hidup memiliki banyak pengertian karena kepuasan hidup sangat subjektif. Puas atau tidaknya hidup manusia tidak ditentukan oleh lingkungan, fisik, kekayaan, dan sebagainya. Kepuasan hidup manusia ditentukan oleh diri sendiri, apakah sudah puas dengan hidup yang dicapainya, nikmat yang diterimanya, dan segala yang ada pada dirinya. Untuk melihat bagaimana tingkat kepuasan hidup pada Aktivis Jama'ah Tablig dapat dilihat pada grafik berikut.

\section{Grafik 2. Tingkat Kepuasan Hidup}

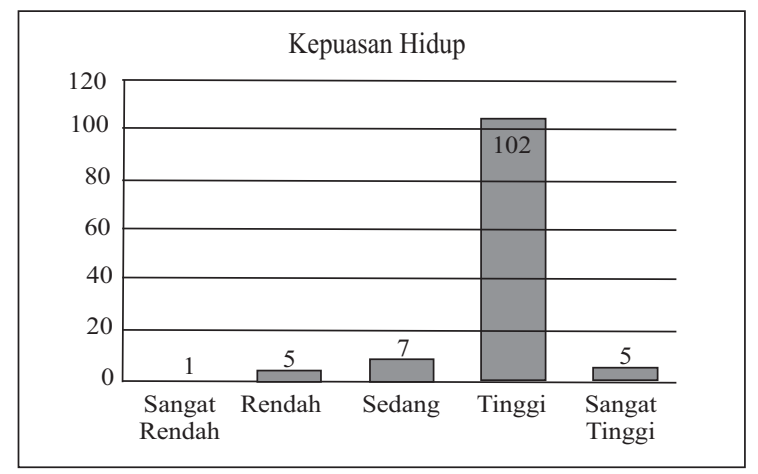

Berdasarkan data di atas, responden yang berada pada tingkat kepuasan hidup yang tinggi dengan 102 orang (78,5\%), berada pada tingkat sangat tinggi sebanyak 5 orang $(3,85 \%)$, tingkat sedang sebanyak 17 orang $(13,1 \%)$, tingkat rendah sebanyak 5 orang $(3,8 \%)$, dan pada tingkat sangat rendah hanya 1 orang saja $(0,8 \%)$. Dari data ini dapat dikatakan bahwa kepuasan hidup pada Aktivis Jama'ah Tablig cenderung tinggi.

Sebagaimana dijelaskan sebelumnya bahwa kepuasan hidup sangat subjektif tergantung sejauh mana individu tersebut berprasangka pada dirinya. Sousa dan Lyubomirsky (2001) menjelaskan bahwa kepuasan hidup adalah penerimaan dirinya pada lingkungan sekitar dan kondisi dirinya dan yang dominan dalam menentukan kepuasan hidup adalah aspek kognitif.

Agama mengajarkan bahwa manusia harus senantiasa memaknai hidupnya dengan positif. Banyak ajaran-ajaran agama membahas hal-hal seperti bersyukur, tawakal, husn alzhann dan qana'ah. Agama melarang manusia untuk merasa putus asa (qunuth). Agama mengajarkan manusia agar senantiasa optimis dalam menjalani hidup.
Segala kekurangan yang ada pada diri harus disikapi dengan merasa cukup (qana'ah). Nikmat yang diberikan harus disikapi dengan taat kepada Allah (syukr). Segala yang akan terjadi, apakah baik atau buruk harus disikapi dengan positif, optimis, usaha, dan berserah diri pada Allah, yakin Allah memberikan yang terbaik (tawakkal). Sesuatu yang buruk yang menimpa kita, baik karena manusia, atau karena kondisi tertentu, harus disikapi dengan prasangka baik (husn al-zhann).

Jika semua ajaran itu dilakukan, tentunya manusia akan hidup dengan kepuasan yang maksimal. Manusia yang senantiasa mengeluh dan tidak pernah puas dengan apa yang diberikan maka hidupnya akan cemas, khawatir, dan penuh dengan penyesalan. Padahal apa yang telah diberikan pada seluruh manusia sangat memuaskan. Manusia yang menyadari akan nikmat Allah akan bisa menikmati puasnya bernapas, puasnya tidur, puasnya makan, puasnya minum, puasnya hidup aman, dan kepuasan nikmat Allah lain yang tidak terhitung jumlahnya.

Dengan demikian jelas bahwa agama sangat relevan dalam membantu manusia mencapai kepuasan hidupnya. Observasi dan wawancara yang peneliti lakukan menunjukkan bahwa tidak sedikit dari Aktivis Jama'ah Tablig yang memiliki masa lalu yang kelam. Hal ini berpotensi membuat mereka merasakan penyesalan terus menerus. Beberapa di antara mereka sebelumnya pernah menjadi preman, pemabuk, dan jauh dari agama. Hal ini sangat wajar karena salah satu target utama Jama'ah Tablig adalah kalanganan menengah ke bawah dan kalanganan pinggiran. Karena bagi mereka kelompok seperti itu lebih mudah untuk diajak dan tidak banyak memiliki kepentingan.

Mereka yang memiliki masa lalu kelam, sangat bersyukur telah mendapat hidayah dari Allah. Mereka menyikapi masa lalunya dengan positif bukan dengan penyesalan yang depresif. Kesalahan masa lalu yang mereka lakukan mereka bayar dengan berbuat baik dan mengabdikan dirinya untuk kepentingan dakwah. Mereka lebih menyibukkan dirinya untuk 
mengerjakan aktivitas-aktivitas dakwah dibandingkan meratapi masa lalunya.

Kekurangan ekonomi yang cukup banyak tidak dianggap sebagai sebuah kesulitan. Pasalnya keyakinan agama mereka yang kuat mengenai konsep rezeki. Mereka yakin bahwa masing-masing individu akan mendapatkan pemeliharan dari Allah. Menurut mereka, manusia yang dekat dengan Allah tentu akan senantiasa mendapat pertolongan dari Allah. Berdasarkan dasa statistik mengenai tingkat ekonomi mereka, nampaknya kebanyakan mereka berada pada tingkat ekonomi menengah (67\%), selanjutnya cukup banyak yang berada pada tingkat ekonomi ke bawah $(20 \%)$, dan paling sedikit mereka yang berada pada tingkat ekonomi ke atas (13\%). Namun kondisi ekonomi demikian tidak menyurutkan kegiatan mereka yang cukup berat untuk melaksanakan usaha dakwah. Bagi mereka yang terpenting bukanlah kekayaan, melainkan kecukupan.

Anggapan subjektif tentang lingkungan, kondisi, dan diri sendiri adalah hal yang menentukan kepuasan hidup. Di sini proses kognitif sangatlah penting (Butler \& Mathews, 2004). Proses kognitif itulah yang memengaruhi mereka untuk menyikapi kondisi hidupnya (Lyubomirsky, King, \& Diener, 2005; Schweingruber, 2006). Anggapan diri secara negatif akan berakibat pada rendahnya kepuasan hidup, bahkan akan menyebabkan depresi (Teasdale, 1983).

Agama sangat relevan dalam mengajarkan manusia untuk menyikapi hidupnya secara positif. Mensyukuri kelebihan yang ada, merasa cukup dengan kekurangan yang ada, dan berserah diri pada Allah adalah cara yang sangat praktis untuk mencapai kepuasan hidup.

\section{Tingkat Keberfungsian Psikologis}

Salah satu indikasi mental yang sehat adalah berfungsinya psikologis secara baik. Psikologis yang baik biasanya mampu mengatasi suatu masalah (Aldwin \& Revenson, 1987). Psikologis yang baik biasanya juga terhindar dari depresi, cemas, takut, dan perasaan-perasaan negatif lain. Berikut tingkat keberfungsian psikologis pada Aktivis Jama'ah Tablig.
Grafik 3. Fungsi Psikologis pada Aktivis Jama'ah Tablig

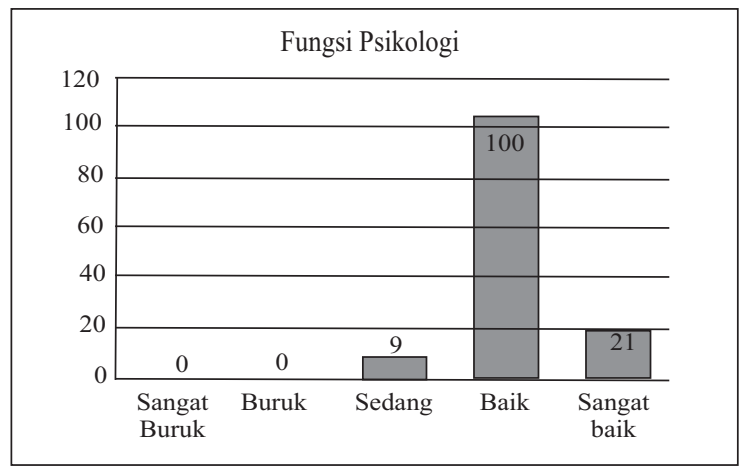

Dari grafik di atas, jelas sekali bahwasanya kebanyakan pada responden menunjukkan baiknya fungsi psikologis, responden yang fungsi psikologisnya tinggi sebanyak 100 orang $(76,9 \%)$, sangat baik sebanyak 21 orang $(16,15 \%)$, sedang sebanyak 9 orang $(6,9 \%)$, dan tidak ada responden yang berada pada tingkat buruk dan sangat buruk. Hal ini menunjukkan bahwa pada responden masih memiliki fungsi psikologis yang normal bahkan baik.

Sebagaimana dijelaskan sebelumnya bahwa jiwa yang berfungsi baik biasanya mampu menyelesaikan masalahnya dan mampu menghadapi kondisi negatif di dalam jiwanya. Hal ini sangat relevan dengan ajaran agama yang mengajarkan manusia bagaimana cara menghadapi suatu masalah (coping). Bahkan saat ini sudah ada pendekatan agama dan spiritual sebagai sebuah coping, bahkan konseling dan psikoterapi (Linne, 2006; Shorrock, 2008). Bahkan Boscalgia (2005) menjelaskan bahwa individu yang jarang melakukan coping dengan agama cenderung lebih banyak mengalami depresi dan kecemasan. Keimanan dan melakukan ibadah keagamaan akan membantu mengurangi stres bahkan mencegah penyakit kronis (Jackson, 2010).

Berdasarkan observasi dan wawancara yang dilakukan peneliti, tampaknya pada Aktivis Jama'ah Tablig diajarkan cara-cara untuk menangani suatu masalah hidup. Mulai dari cara yang bersifat real sampai cara yang bersifat spiritual. Cara yang bersifat real contohnya dengan pendekatan dukungan sosial. Mereka membangun kedekatan antara satu sama lain 
sehingga ketika ada masalah keuangan, pendidikan, pekerjaan, dan sebagainya, mereka bisa saling bekerja sama. Dukungan sosial ini nanti akan lebih banyak dibahas pada bagian berikutnya yaitu relasi dengan orang lain.

Cara yang bersifat spiritual lebih banyak mereka lakukan. Mereka punya caracara spiritualistik ketika menghadapi masalah. Doktrin utama mereka adalah jika mereka mendapat masalah, maka sebenarnya dirinya sedang jauh dari Allah dan harus segera mendekatkan diri pada Allah. Bagi mereka, masalah hidup adalah teguran dari Allah. Mereka yakin, masalah hidup tidak akan datang kecuali ada kemaksiatan dan dosa yang dilakukan, maka manusia harus senantiasa mengevaluasi dirinya ketika mereka menjumpai masalah hidup.

Salah satu cara mereka melakukan coping adalah dengan melakukan i'tikaf di masjid (biasanya sekaligus mengikuti program khuruj). Pernah peneliti melihat salah satu di antara mereka yang sudah menyelesaikan tugas khuruj-nya dan seharusnya sudah pulang, namun dia kembali ke masjid, dan mengatakan bahwa dirinya merasa tidak nyaman karena banyak godaan-godaan di luar sana. Akhirnya dia lebih memilih memperpanjang program khuruj-nya. Apa yang dilakukan oleh dia bisa dikatakan jenis emotional focus coping, di mana individu melakukan coping dengan menghadirkan atau mendekati situasi emosi yang lebih nyaman ketimbang harus menghadapi situasi stres.

Bentuk emotional focus coping yang secara otomatis terjadi pada mereka adalah dengan mengingat akhirat. Mereka selalu mementingkan urusan akhirat, agama, dan umat, sehingga mereka melupakan masalahmasalah hidup yang sebenarnya kecil dibanding masalah akhirat. Salah satu doktrin mereka yang cukup kuat adalah kepeduliannya terhadap umat. Mereka harus memikirkan umat. Mereka biasa menyebutnya dengan istilah "risau dengan umat....risau dengan akhirat." Bagi mereka, seharusnya manusia bukan risau dengan dunia melainkan risau dengan akhirat.

Salah satu pendekatan spiritual lain dalam menghadapi masalah adalah dengan berdoa, meminta ampunan Allah, bertaubat, dan berusaha mendekatkan diri pada Allah. Bahkan mereka memiliki doa khusus agar dijauhkan dirinya dari permasalahanpermasalahan. Mereka menyebut doa itu adalah $d u^{\prime} a$ al-hirz yang isinya berupa kumpulan ayat-ayat Al-Qur'an. Mereka yakin jika mereka berdoa dan bertaubat maka Allah akan mencabut segala permasalahan hidupnya. Tampaknya memang hal ini diajarkan dalam Al-Qur'an surat Al-Thallaq ayat 2-3:

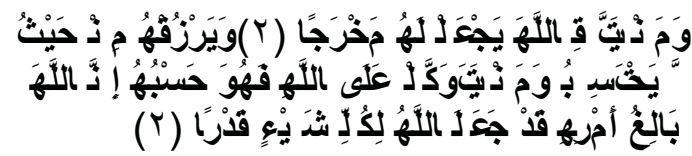

"Barangsiapa bertakwa kepada Allah niscaya Dia akan Mengadakan baginya jalan keluar (2). Dan memberinya rezeki dari arah yang tiada disangka-sangkanya. Dan Barangsiapa yang bertawakal kepada Allah niscaya Allah akan mencukupkan (keperluan)nya. Sesungguhnya Allah melaksanakan urusan yang (dikehendaki)Nya. Sesungguhnya Allah telah mengadakan ketentuan bagi tiap-tiap sesuatu. (3)"

Semua ini menjelaskan bahwa agama sangat relevan sebagai pendekatan coping. Jika mempelajari agama lebih dalam lagi, tentunya akan membantu lebih banyak lagi. Masih ada konsep tawakal yang merupakan bentuk integrasi coping antara problem focus coping dan emotional focus coping. Tawakal adalah gabungan antara usaha menyelesaikan masalah sekaligus berserah diri pada Allah. Konsep semacam ini tidak akan bisa ditemukan kecuali dari agama.

\section{Relasi yang Baik dengan Orang Lain}

Salah satu ciri jiwa yang sehat adalah mampu berbuat baik dan bergaul dengan baik kepada orang lain. Stewart-Brown (2008) menjelaskan bahwa orang yang memiliki mental sehat mampu membangun relasi yang baik dengan orang lain. Individu tersebut juga mampu mengelola hubungan itu dan menjadikan hubungan itu bermanfaat. Berikut tingkat relasi yang baik dengan orang lain pada Aktivis Jama'ah Tablig. 


\section{Grafik 4. Kualitas Relasi yang Baik dengan Orang Lain}

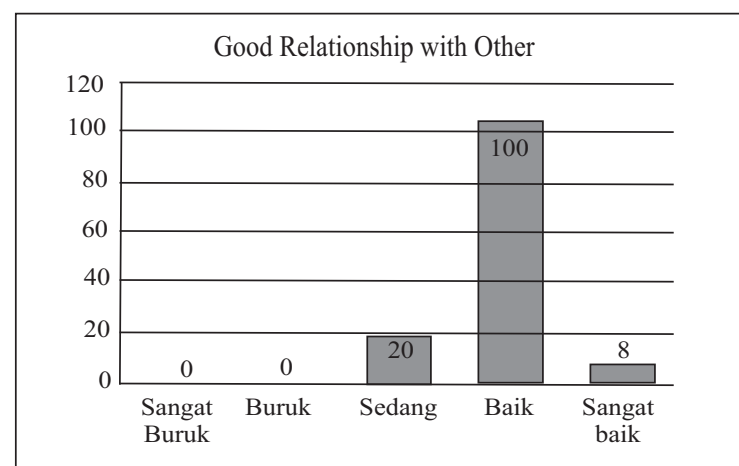

Tentu saja agama mengajarkan manusia untuk berhubungan baik dengan sesama manusia. Bahkan dalam agama ada yang disebut ikatan dengan sesama manusia (habl ma'a al-naas). Tidak sempurna seseorang jika hanya mementingkan hubungan dirinya dengan Tuhan saja (habl ma'a Allah) tanpa mementingkan hubungan dengan sesama manusia. Itulah yang melatarbelakangi Jama'ah Tablig untuk melakukan penyebaran dakwah. Salah satu prinsipnya adalah kepedulian, khususnya kepedulian akan akhirat. Ajaran mereka mewajibkan mereka untuk terbuka bagi semua golongan, bahkan dalam membangun hubungan, mereka dilarang menjalin hubungan karena ada kepentingan tertentu. Mereka yang telah masuk ke dalam Jama'ah Tablig harus melepaskan status sosialnya, kekayaannya, jabatannya, golongan, suku, atau ras. Peneliti melihat ketika ta'lim bulanan di Masjid Kebon Jeruk mereka sangat terlihat setara, tidak ada golongangolongan ataupun status, mereka duduk bersama, berpakaian mirip (biasanya gamis), dan makan bersama dalam satu tempat makan. Berdasarkan wawancara peneliti dengan salah seorang Aktivis senior mereka, diketahui bahwa Jama'ah Tablig menolak bantuan, kerja sama, atau donasi dari pejabat, partai, atau apapun. Mereka khawatir pergerakan mereka akan dimanfaatkan untuk kepentingan tertentu.

Beberapa dari Aktivis Jama'ah Tablig menolak untuk disebut kelompok Jama'ah Tablig. Mereka tidak suka sebutan Jama'ah Tablig, karena beberapa di antara mereka menyadari dengan adanya istilah bagi pergerakannya, maka sama saja mereka mengelompokkan diri dan tentunya bertentangan dengan prinsip keterbukaan. Tidak heran jika dalam kesehariannya, mereka jarang menyebut istilah Jama'ah Tablig.

Salah satu prinsip mereka yang mendasarinya adalah salah satu poin dari enam sifat (siffah al-sittah), yaitu prinsip ikram al-muslimin (saling memuliakan kaum muslimin). Prinsip ini yang menyebabkan mereka jauh dari perpecahan. Mereka tidak berambisi apapun dan tidak punya kepentingan apapun. Bahkan lebih ekstrem lagi, mereka tidak menganjurkan untuk melakukan kajian-kajian yang membawa perbedaan pendapat, seperti kajian fikih, mazhab, apalagi teologi. Mereka hanya mengkaji kitab-kitab yang diajarkan turun temurun di kalangan mereka seperti kitab Fadhaa'il al-'Amal. Mereka sangat ketat dalam memberikan ajaran agama karena kekhawatirannya akan perpecahan. Mereka hanya membolehkan kitab yang dikaji adalah kitab yang diterbitkan oleh Masjid Kebon Jeruk.

Salah satu contohnya adalah ketika beberapa kelompok agama menyebut bahwa banyak di antara hadis-hadis dalam kitab Fadhaa'il al-'Amal berpredikat lemah (dha'if). Oleh karena itu, mereka membuat upaya tahqiq (penyuntingan) dari kitab itu dan menerbitkannya kembali. Salah satu motifnya adalah menjauhi perpecahan umat. Mereka sangat menjauhi perdebatan furuu'iyyah (cabang). Konflik pendapat terkadang pernah terjadi, namun tidak sering dan segera diselesaikan oleh pimpinan (mereka menyebutnya amir) mereka.

Sekalipun terkesan tidak ada golongan-golongan tertentu, namun mereka memberikan penghormatan lebih pada kader-kader mereka (mereka menyebutnya karkun bagi laki-laki dan masturah bagi wanita) yang istimewa. Karkun yang lebih sering khuruj selama bertahun-tahun, sampai keluar negeri, ke pelosok-pelosok, mereka lebih cenderung dihormati. Mereka yang hafal Al-Qur'an dan hadis juga lebih dihormati. Mereka yang hafal Al-Qur'an disebut dengan istilah maulana. Mereka yang hafal Al-Qur'an, sekaligus hadis, dan memiliki wawasan agama dan kemampuan 
agama yang baik mereka sebut dengan $m u f t i$. Merekalah yang menjadi puncak tertinggi bagi Jama'ah Tablig. Namun demi kepentingan kesatuan Islam, mereka tidak memperlihatkan secara jelas struktur tersebut. Struktur yang mereka miliki sulit untuk dideteksi dan hanya diketahui oleh beberapa dari mereka saja demi menjaga kesatuannya dan menghindari ambisi-ambisi kader internal.

Mereka tidak memiliki struktur formal, namun mereka membagi-bagi kepemimpinan mereka dalam beberapa wilayah. Di setiap wilayah, ada beberapa pemimpin. Mereka tidak menggunakan pemimpin tunggal karena mengedepankan musyawarah. Di tingkat negara, mereka dipimpin oleh beberapa para mufti. Di tingkat program khuruj, mereka menggunakan pemimpin tunggal. Setiap program khuruj harus dipimpin oleh satu pemimpin. Untuk mencegah konflik, mereka mengganti pemimpin perjalanan dalam durasi setiap beberapa hari atau beberapa minggu. Mereka sangat mengedepankan persatuan dan musyawarah. Bahkan kegiatan-kegiatan besar yang mereka lakukan disebut dengan istilah musyawarah bulanan atau musyawarah tahunan.

Hedges (2008) juga menjelaskan bahwa mereka mampu menyebar dengan cepat karena memiliki kesatuan perintah. Mereka melakukan penyebaran baik secara perorangan (face to face), rumah ke rumah (door to door proselytization). Mereka menghindari cara-cara dengan pendekatan media cetak atau internet karena menghindari eksklusivitas. Ketika praktik khuruj, satu kelompok mereka dalam berdakwah kira-kira sepuluh anggota, misi dilakukan dengan waktu yang bervariasi. Selama misi mereka dituntut untuk mandiri. Mereka mengutamakan target dakwah yang mudah disampaikan. Adapun pada misi yang panjang, biasanya mereka bepergian hingga ke luar negeri dan pelosok-pelosok. Tempat mereka tinggal ketika misi khuruj adalah masjid. Ketika kembali ke wilayahnya, mereka berkewajiban berdakwah di sekitarnya.

Di setiap wilayah, mereka berkewajiban untuk menjalin hubungan baik dengan lingkungan dan tetangga. Mereka diwajibkan menghidupkan masjid di dekat rumahnya. Namun ketika masjid itu sudah dihidupkan oleh kelompok Islam lain, mereka cenderung menghindar untuk aktif di dalamnya, kecuali hanya beribadah. Tujuan mereka adalah menjauhi konflik. Pada lingkungan keluarga, mereka berusaha untuk mengajak istri dan anak-anak mereka agar sepaham dengan ideologi mereka. Hal ini bertujuan agar mempermudah upaya dakwah mereka.

Aspek keluarga adalah aspek yang paling banyak mendapat kritikan dari masyarakat dan kelompok Islam lain. Kritik masyarakat yang paling banyak adalah mereka dianggap tidak bertanggung jawab karena meninggalkan anak dan istri pergi jauh demi misi khuruj. Masyarakat menganggap mereka tidak memberikan nafkah secara baik, jika nafkah lahir terpenuhi, belum tentu nafkah batin terpenuhi. Kritik ini yang selalu disebarkan oleh masyarakat untuk melabel gerakan Jama'ah Tablig.

Setelah peneliti melakukan penelusuran terhadap kehidupan keluarga mereka. Ternyata mereka melakukan upayaupaya untuk memenuhi kebutuhan keluarga yang ditinggal khuruj. Upaya yang paling utama adalah mengajak mereka untuk peduli dengan dakwah. Mereka selalu mengajak anak laki-laki mereka untuk ikut dalam kegiatan Jama'ah Tablig. Apabila anak dan istri sudah paham dan mendukung, maka sesungguhnya tidak ada masalah dengan keluarga. Setiap kader diwajibkan untuk memberikan ta'lim rutin di keluarganya, hal ini bertujuan untuk memberikan pemahaman mendalam tentang agama kepada mereka. Upaya selanjutnya adalah dengan memberikan biaya-biaya yang cukup untuk keluarga selama mereka ditinggal khuruj. Mereka yang tidak punya biaya cukup, akan dibantu oleh sesama mereka di wilayahnya, dan itu sudah menjadi tanggung jawab semua aktivis di setiap wilayah. Mereka yang tidak melakukan upaya-upaya itu, maka mereka dianggap lalai dari tanggung jawab dan bisa dikatakan tidak bertanggung jawab.

Agama sangat mendukung manusia untuk berinteraksi baik dengan sesamanya. 
Sejauh mana jama'ah agama mampu mendukung dan saling peduli sesamanya (Krause, 2002). Jama'ah yang saling mendukung tentu akan memengaruhi psikologis individu di dalamnya dan akan berpengaruh pada kebahagiaan dan afeksi tiap individu (Liping, 2005). Selain saling membantu satu sama lain di antara mereka, dengan berjama'ah, individu akan saling menghargai. Brown dkk (1986) menjelaskan bahwa dukungan sosial akan berpengaruh pada penghargaan diri, kurangnya dukungan sosial dapat menyebabkan risiko peningkatan depresi ketika stres. Antonucci (1986) serta Schultz dan Deker (1985) menjelaskan bahwa kedekatan dengan komunitas akan berpengaruh pada kebahagiaan. Juga berpengaruh terhadap kualitas hidup Abbey dkk, 1985). Berjama'ah, tentunya mereka akan terhindar dari kesendirian, sehingga akan merasa bahagia (McAuley dkk, 2000). Bahkan akan berpengaruh pada kesehatan fisik (Wallston, Alagna, Devillis, \& Devillis 1983). Hal ini disebabkan ada kaitan antara kebahagiaan dan kesehatan fisik (Gerdtham \& Johannesson, 1997).

Inilah pentingnya konsep berjama'ah dalam agama. Islam mengajarkan manusia untuk berjama'ah. Dengan berjama'ah maka kesempatan untuk saling tolong menolong dalam kebaikan lebih besar (al-ta'aawan 'alaa al-birr). Tentunya hal ini akan bermanfaat secara luas, baik secara psikologis, sosial, bahkan finansial.

\section{Realisasi Diri}

Salah satu ciri mental yang sehat adalah individu yang mampu merealisasikan dirinya atau sedang berusaha merealisasikan dirinya. Konsep realisasi diri sangat dominan diperkenalkan oleh Abraham Maslow yang menjelaskan bahwa manusia memiliki kebutuhan untuk mencapai realisasi diri. Bahkan Carl Rogers mengatakan bahwa insting utama manusia adalah mengaktualisasikan dirinya. Semua manusia berkeinginan untuk merealisasikan dirinya. Namun sebenarnya konsep aktualisasi lebih jauh diperkenalkan oleh Aristoteles yang mengatakan bahwa seluruh makhluk diciptakan untuk mengaktualisasikan dirinya. Seluruh makhluk harus bergerak dari potensi kepada aktus. Potensi manusia adalah rasionalitas, maka manusia harus mengaktualkan potensi rasionalnya sehingga mencapai tujuan hidupnya. Ketika tujuan ini tercapai, maka manusia akan merasa bahagia dan memiliki jiwa yang baik (eudaimonia/ well-being).

Adapun untuk memahami bagaimana tingkat realisasi diri pada Aktivis Jama'ah Tablig dapat dilihat pada grafik di bawah ini.

\section{Grafik 3.6 Realisasi diri pada Aktivis Jama'ah Tablig}

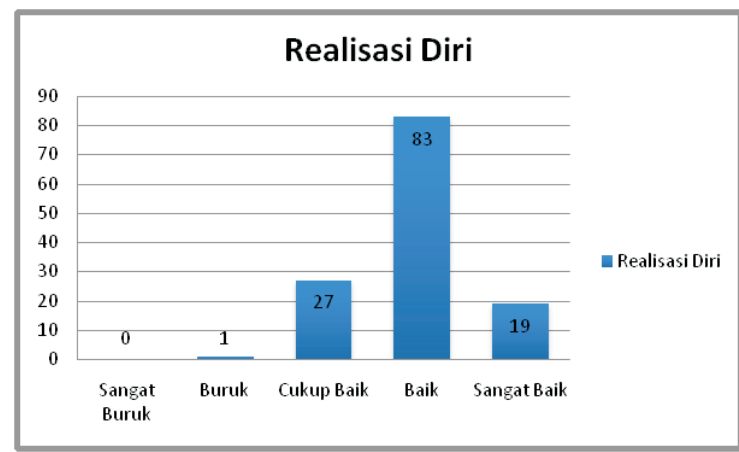

Dari data di atas dapat diketahui bahwa kebanyakan responden dapat melakukan realisasi diri dengan baik sebanyak 83 orang $(63,8 \%)$. Responden yang dapat melakukan realisasi diri dengan sangat baik sebanyak 19 orang $(14,62 \%)$, responden yang cukup baik dalam melakukan realisasi diri sebanyak 27 orang $(20,8 \%)$, responden yang buruk dalam melakukan realisasi diri hanya 1 orang $(0,8 \%)$, dan tidak ada responden yang sangat buruk dalam melakukan realisasi diri. Dengan demikian dapat dipahami bahwa kebanyakan Aktivis Jama'ah Tablig mampu melakukan realisasi diri dengan baik, bahkan cukup banyak di antaranya yang sangat baik dalam melakukannya.

Agama sangat tegas menjelaskan tujuan hidup manusia. Allah menciptakan manusia untuk mengaktualkan dan merealisasikan suatu misi. Misi ini adalah misi yang mulia dan membawa kebaikan serta kebahagiaan. Para ulama terdahulu menjelaskan sangat terperinci apa tujuan hidup manusia. Al-Ghazali (t.t.) menjelaskan bahwa tujuan hidup manusia adalah untuk menuju Allah. Maka di dunia, manusia harus 
mengaktualkan dirinya dalam bentuk kedekatan diri dengan Tuhan, mempersiapkan jiwa, akal, dan badan untuk melakukan perjalanan kepada Allah.

Beberapa pendapat lain mengatakan tujuan hidup manusia adalah untuk menjadi pemimpin di muka bumi ini. sebagaimana yang dijelaskan dalam surat Al-Baqarah ayat 30 dan surat Shaad ayat 26. Allah berfirman:
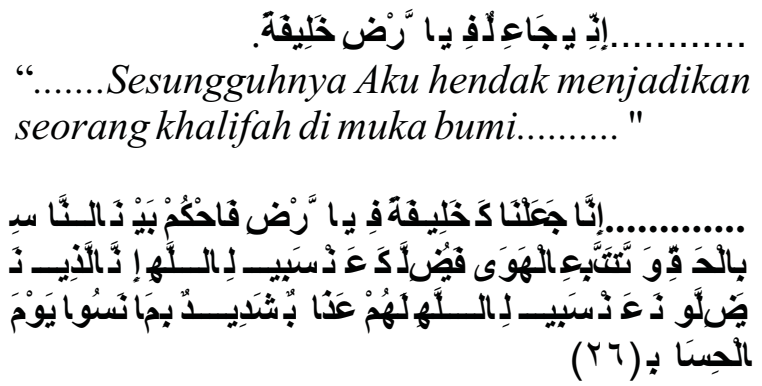

“......Sesungguhnya Kami menjadikan kamu khalifah (penguasa) di muka bumi, Maka berilah keputusan (perkara) di antara manusia dengan adil dan janganlah kamu mengikuti hawa nafsu, karena ia akan menyesatkan kamu dari jalan Allah. Sesungguhnya orang-orang yang sesat dari jalan Allah akan mendapat azab yang berat, karena mereka melupakan hari perhitungan."

Begitulah Allah memerintahkan manusia untuk merealisasikan misi utamanya, yaitu menjadi perwakilan Allah di muka bumi. Manusia adalah perwakilan Allah, maka manusia memiliki potensipotensi ketuhanan yang bisa diaktualisasikan, seperti potensi pencipta (kreatif), potensi pengasih dan penyayang, potensi maha adil (seimbang), potensi mengatur (sistematis), dan potensi-potensi lainnya. Manusia juga tidak terlepas dari makhluk fisik dengan badan mirip hewan namun badan paling sempurna. Potensipotensi hewan juga ada dalam diri manusia. Menurut Muhammad Iqbal, Manusia yang mengaktualkan potensi ketuhanannya adalah manusia yang sempurna (insaan kaamil). Sedangkan manusia yang hanya mengaktualkan potensi hewannya, seperti hidup untuk makan (nutritif), melampiaskan seks (reproduktif), dan menyakiti orang lain (predator), tidak ubahnya seperti hewan bahkan lebih hina dari pada hewan (bal hum adhall).

Pada surat Shaad ayat 26 sudah sangat terperinci dijelaskan bagaimana cara manusia untuk mencapai misinya untuk menjadi wakil Allah di muka bumi (insaan kaamil). Yaitu dengan cara berbuat adil dan tidak selalu mengikuti nafsu syahwat dan nafsu hewan. Itulah hakikat realisasi diri berdasarkan surat tersebut.

Wilcox (2007) mengatakan bahwa dalam sufisme, semua orang memiliki potensi kesempurnaan di dalam dirinya. Aktualisasi diri manusia adalah dengan merealisasikan potensi tersebut. Sedangkan cara untuk mencapai potensi tersebut dengan mencari kedamaian, kebenaran, dan mengenal Tuhan, sehingga manusia secara bertahap akan mendapatkan dirinya menuju aktualisasi diri yang hakiki. Akhir dari aktualisasi diri ini adalah penyatuan terhadap Tuhan.

Ketika harus merealisasikan diri, manusia tidak harus menjadi pemimpin formal, siapapun bisa merealisasikan dirinya selama hidupnya yang bertujuan untuk mendekatkan diri pada Allah dengan cara menyempurnakan jiwanya. Jika realisasi diri bersifat duniawi, tentunya manusia banyak yang putus asa jika tidak mencapainya, bahkan tidak jarang di antara mereka melakukan hal-hal curang. Ataupun jika realisasi diri duniawi tersebut tercapai, maka pada titik itu justru bukan menjadi titik kebahagiaan, melainkan titik kejenuhan, karena apa yang sudah diimpikan sudah dicapai dan tidak tahu lagi harus apa dia hidup. Jika demikian, apakah bisa dikatakan itu realisasi diri yang hakiki?

Agama mengajarkan realisasi diri yang hakiki. Realisasi diri yang bisa dicapai oleh semua orang, yang memberikan kebahagiaan tidak terhingga jika mencapainya. Realisasi diri yang akan terus berlangsung baik sebelum kematian badan maupun sesudah kematian badan. Agama mengajarkan manusia untuk mencapai kehidupan akhirat yang bahagia, sementara kehidupan di dunia hanya sekedar tempat kecil dengan waktu yang singkat agar berbekal untuk akhirat yang luas dan kekal.

Pada aktivis Jama'ah Tablig, ajaran 
mereka mengenai hari akhir sangat kuat. Mereka tidak akan melakukan kegiatan agama yang begitu berat, menghabiskan biaya, dan mengorbankan banyak hal kalau bukan karena suatu keyakinan yang tertanam kuat yaitu keyakinan akan kehidupan akhirat. Bagi mereka, hidup di dunia adalah usaha agar di akhirat bisa aktual. Usaha itulah yang disebut realisasi diri.

Secara empiris, telah banyak penelitian yang menjelaskan bahwa agama membantu manusia dalam merealisasikan dan mengaktualisasikan dirinya. Watson (1990) menjelaskan bahwa orientasi intrinsik agama berkorelasi signifikan dengan aktualisasi diri. Stones (1980) menjelaskan bahwa orang yang memiliki komitmen agama yang baik menunjukkan aktualisasi diri yang baik.

Agama mengajarkan kepada manusia makna hidup dan tujuan hidup untuk direalisasikan. Kebahagiaan hanya bisa dicapai dengan menjadikan agama sebagai sistem kebermaknaan hidup (Silberman, 2005). Pencarian akan makna hidup sangat tepat dengan tradisi-tradisi agama (Pargament, 1997). Tentu saja agama mengajarkan makna hidup yang bersifat ukhrawi. Makna yang hidup yang selalu mendatangkan kebahagiaan dan kesejahteraan.

Doktrin Jama'ah Tablig mengenai akhirat sangat kuat. Inilah yang menjadi kekuatan bagi mereka untuk melakukan aktivitas keagamaanya. Agama mengajarkan bahwa kehidupan akhirat adalah tujuan, adapun kehidupan dunia adalah ujian. Beberapa filosof muslim menganggap bahwa kehidupan dunia adalah ilusi (la'ib wa $l a h w)$, dan kehidupan akhirat adalah realita. Tampaknya hal ini juga dikuatkan oleh ayat Al-Qur'an surat Al-Taubah ayat 38:

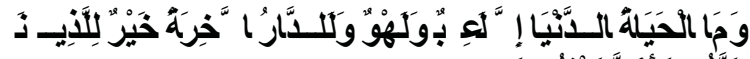

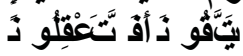

"Dan Tiadalah kehidupan dunia ini, selain dari main-main dan senda gurau belaka. Dan sungguh negeri akhirat itu lebih baik bagi orang-orang yang bertakwa. Maka tidakkah kamu memahaminya?"
Hal senada juga diungkapkan oleh firman Allah dalam surat Al-Taubah ayat 38:

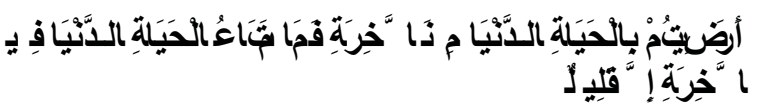

"Apakah kamu puas dengan kehidupan di dunia sebagai ganti kehidupan di akhirat? Padahal kenikmatan hidup di dunia ini (dibandingkan dengan kehidupan) diakhirat $h a n y a l a h \quad s e d i k i t$. "

Hal ini juga disampaikan oleh firman Allah dalam surat Al-Ra'd ayat 26:

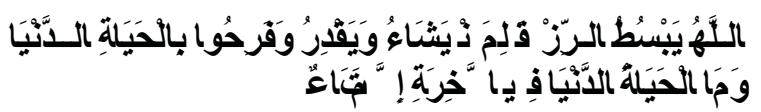

"Allah meluaskan rezeki dan menyempitkannya bagi siapa yang Dia kehendaki. Mereka bergembira dengan kehidupan di dunia, Padahal kehidupan dunia itu (dibanding dengan) kehidupan akhirat, hanyalah kesenangan (yang sedikit)."

Dalam surat Ghafir ayat 39 juga dijelaskan hal yang serupa bahwasanya kehidupan dunia adalah kenikmatan sedikit saja. Adapun kehidupan akhirat adalah kehidupan permanen.

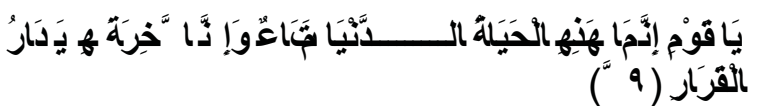

"Hai kaumku, sesungguhnya kehidupan dunia ini hanyalah kesenangan (sementara) dan Sesungguhnya akhirat itulah negeri yang kekal."

Ayat ini sangat jelas menyampaikan bahwa aktualisasi dan realisasi diri yang paling sempurna adalah realisasi ukhrawi. Realisasi duniawi hanya membawa kebahagiaan yang sedikit. Hakikat realisasi diri bukanlah mencapai jabatan tertentu, gelar tertentu, kekayaan tertentu, kehormatan tertentu, ataupun status tertentu. Hakikat realisasi diri adalah pencapaian kualitas jiwa, karena hanya jiwa yang bersifat ukhrawi. Mendidik jiwa menjadi berkualitas adalah bentuk aktualisasi diri.

Beriman kepada hari akhir, pada jiwa 
yang bersifat ukhrawi sangat penting. Meyakini kehidupan setelah kematian mendatangkan manfaat yang besar bagi psikologis. Flanelly (2006) mengatakan bahwa orang yang memiliki keyakinan akan kehidupan setelah kematian cenderung menunjukkan simptom gangguan mental yang rendah. Bahkan keyakinan itu berpengaruh pada penyembuhan penyakit menjadi lebih cepat (King, 1999).

Keyakinan metafisik yang begitu kuat tampaknya dipengaruhi oleh akar pemikirannya. Menurut Haron (2009), Jam'ah Tablig juga berakar pada sufisme. Justru akar ini yang menjadi semangat bagi anggotanya dan menarik bagi orang. Noor (2009) mengatakan bahwa Jama'ah Tablig mengadopsi ritual-ritual sufi yang cocok bagi mereka. Namun kesemuanya itu menunjukkan bahwa keyakinan metafisik dan keyakinan alam akhirat adalah penting.

\section{PENUTUP}

Penelitian ini membuktikan bahwa mengikuti komunitas keagamaan, melakukan ibadah keagamaan secara rutin, meyakini doktirn-doktrin agama, dan mengamalkan ajaran-ajaran agama tidak menunjukkan adanya tanda-tanda gangguan mental atau kesehatan mental yang rendah. Hal ini terbukti baik dari alat ukur kesehatan mental secara umum dan setiap aspek kesehatan mental, memiliki kecenderungan kesehatan mental yang tinggi bahkan beberapa di antaranya sangat tinggi.

Tanpa agama manusia sulit untuk menjalani hidup yang teratur dan sesuai. Agama ibarat ajaran Tuhan yang berisi pengetahuan yang begitu banyak yang bersifat praktis sehingga jika diikuti akan membawa kepada kebahagiaan. Pencarian kebenaran tanpa memperhatikan agama tidak akan bisa sempurna. Jika manusia mencari kebenaran untuk suatu permasalahan, tentu dibutuhkan waktu bertahun-tahun, namun agama sudah menyimpulkannya dalam satu atau beberapa kalimat bahkan dapat dipraktikkan secara mudah. Maka peneliti memberikan rekomendasi untuk penelitian selanjutnya agar memberikan nuansa religius pada tulisan-tulisan ilmiah karena ajaran-ajaran agama banyak mendahului temuan-temuan ilmiah. Bagi peneliti, pendapat yang mengatakan bahwa ayat Al-Qur'an atau hadis tidak pantas dimuat dalam tulisan ilmiah sesungguhnya upaya untuk menjauhkan pengetahuan dari agama, dapat dikatakan itu adalah upaya provokasi sekularisasi ilmu pengetahuan. Sebagai manusia beragama, tentu tidak masalah bagi kita memuat ajaran agama berupa kutipan ayat atau hadis dalam karyailmiah.

Peneliti menggunakan sumber penelitiannya adalah Jama'ah Tablig sematamata sebagai perwakilan dari salah satu pergerakan Islam yang menyebarkan dakwah dan melakukan aktivitas keagamaan dengan sangat intensif. Pemilihan Jama'ah Tablig sebagai sumber penelitian sematamata karena keterbatasan peneliti yang tidak sanggup meneliti seluruh perwakilan pergerakan agama. Adapun kritik yang dilancarkan masyarakat kepada pergerakan Jama'ah Tablig bukan menjadi kajian dalam penelitian ini, karena perspektif penelitian ini adalah mengkaji aspek kesehatan mental secara positif. Peneliti memberikan rekomendasi pada penelitian selanjutnya agar meneliti pergerakan Islam lain, sehingga dapat menjadi pelengkap, atau bahkan mengkritisi penelitian ini.

\section{DAFTAR PUSTAKA}

Abbey, A., Abramis, D., \& Caplan, R. D. (1985). Effects of different sources of social support and social conflict on emotional well-Being. Journal of Basic and Applied Social Psychology, 6(2), 111-129.

Aldwin, M. \& Revenson, A.( 1987). Does coping help? A reexamination of the between coping and mental health. Journal of Personality and Social Psychology, 53 (2), 337-348.

Albernaz, A. (2011). Study examines link between poverty, Mental Illness. Official Web Sites of New England Psychologist, 18(11). (t.t.) 
Al-Ghazali. Ihya' 'ulum al-din. Diuduh dari: $M a w q i$, al - Waraq. http://www.alwarraq.com.

Antonucci, T.C., \& Israel, B. A. (1986). Veridicality of social support: A comparison of principal and network members' responses. Journal of Consulting and Clinical Psychology, $54(4), 432-437$.

Bilsker, D., Wiseman, S., \& Gilbert, M. (2006). Managing depression-related occupational Disability: A pragmatic approach. Can J Psychiatry, 5(2), 76.

Boscaglia, N., Clarke, D.M., Jobling, T.W., \& Quinn, M.A. (2005). The Contribution of spirituality and spiritual coping to anxiety and depression in women with a Recent diagnosis of gynecological cancer. International Journal of Gynecological Cancer, 15(5), 755761.

Brown, G.W., Andrew, B., Harris, T., Adler, Z., \& Bridge, 1. (1986). Social support, self-esteem and depression. Psychological Medicine Cambridge University Press, 16, 813-831.

Butler. G,. \& Mathews, A. (1983). Cognitive processes in anxiety. Advances in Behaviour Research and Therapy, 5(1), 51-62.

Davis, T.L., Kerr, B.A., \& Kurpius, S.E.R. (2003). Meaning, purpose, and religiosity in at-risk youth: The relationship between anxiety and spirituality. Journal of Psychology and Theology, 31.

Diener, E., \& Biswas-Diener, R. (2009). Happiness unlocking the mysteries of psychological wealth. Blackwell Publishing.

Flannelly, K.J., Koenig, H.G., Ellison, C.G., Galek, K., \& Krause, N. (2006). Belief in life affter death and mental health: Findings from a national survey. Journal of Nervous \& Mental Disease, 194(7), 524-529.

Gerdtham, U., \& Johannesson, M. (1997). The Relationship between happiness, health and socio-economic factors: Results based on swedish micro data. Working Paper Series in Economics and Finance, 207(1).

Haron, M. (2009). The Dawa movement and sufi tariqat. Departemen of Theology \& Religious Study University of Botswana, 1.

Hedges, J.W. (2008). Tabligi jamaat: the premier latent network. Threat Convergence Occasional Research Series, the Fund for Peace.

Jackson, B.K. (2010). Families coping with cronic pain: A brief summary of research study. Diunduh dari: http://www.familypainstudy.com/Fa milyPainStudy.summary.brief.pdf.

Kaczorowski, J.M. (1990). Spiritual wellbeing and anxiety in adults diagnosed with cancer. The Hospice Journal, 5 (3\&4), 105-116.

King, L.A., \& Napa, C.K. (1998). What makes a life good. Journal of Personality and Social Psychology, Copyright 1998 by the American Psychological Association, Inc, 75 (1), 156-165.

King, M., Speck, P., \& Thomas, A. (1999). The effect of spiritual beliefs on outcome from illness. Journal of Social Science \& Medicine. 48, 12911299.

Krause, N. (2002). Religious meaning and subjective well-being in late wife. The Journals of Gerontology, Series B 58 (3), 160-170.

Linne, D. (2006). Spirituality in counselling and psychotherapy. London: SAGE 
Publications Ltd. 2006.

Liping. (2005). The relationship between happiness and social support. Journal of Chinese Psychology Acta Psychologica Sinica. 15(30), 1.

Lyubomirsky, S., King, L., \& Diener, E. (2005). The Benefits of frequent positive affect: Does happiness lead to success?. Psychological Bulletin, 131, 803-855.

McAuley, E., Blissmer, B., Marques, D.X., Jerome, G.J., Kramer, A.F., \& Katula, J. (2000). Social Relations, physical activity, and well-being in Older Adults. Journal of Preventive Medicine. 31 (5), 608-617.

Noor, F.A. (2009). The Spread of the Tabligi Jamaat Across Western, Central, and Eastern Java and the Role of the Indian Muslim Diaspora. $S$. Rajaratnam School of International Studies Singapore.

Paloutzian, R.F \& Park, C.L. (2005). Handbook of The psychology of religion and spirituality. New York: The Guildford Press.

Pargament, K.I. (1997). The bsychology of religion and coping. New York: The Guildford Press.

Saraceno, B., \& Barbui, C. (1997). Poverty and mental Illness. Can J Psychiatry, 42.

Schulz, R., \& Decker, S. (1985). Long-term adjustment to physical disability: The role of social support, perceived control, and self-blame. Journal of Personality and Social Psychology. $48(5), 1162-1172$.

Schweingruber, D. (2006). Success through a positive mental attitude?: The role of positive thinking in door-to-door Sales. The Sociological Quarterly, 47, Midwest Sociological Society,
41-68.

Seligman, M.E.., Steen, T.A., Park, N., \& Peterson, C. (2005). Positive psychology progress empirical validation of interventions. American Psychological Association 0003066X/05/\$12.00. 60(5), 410-421 DOI: $10.1037 / 0003-066 X .60 .5 .410$, 414.

Shorrock, A (2008). The Transpersonal in Psyychology, psychotherapy and counselling. New York: Palgrave Macmillan.

Silberman, I. (2005). Religion as a meaning system: Implications for the new Millennium. Journal of Social Issues. 61(4), 641-663.

Sousa, L., \& Lyubomirsky, S. (2001). Life satisfaction. In J. Worell (Ed.), Encylopedia of women and gender: Sex similarities and differences and the impact of society on gender Vol. 2, San Diego, CA: Academic Press, 667-676.

Stewart-Brown, S., Hu, Y.J., Twigg, L. Weich, S. (2007). Can the 12 item general health questionnaire be used to measure positive mental health? Psychological Medicine, 37,10051013.

Stones, C.R. (1980). A Jesus community in south africa: Self-actualization or need for security?. Psychological Reports. 46(1), 287-290.

Teasdale, J.D. (1983). Negative thinking in depression: Cause, effect, or reciprocal elationship?. Advances in Behaviour Research and Therapy. 5(1), 3-25.

Vogelsang, I. (1999). Economic aspect of mental health carve-outs. The Journal of Mental Health Policy and Economics J. Mental Health Policy Econ. 2,29-41. 
Wallston, B.S., Alagna, W.S., Devillis, B.M., \& Devillis, R.V. (1983). Social support and physical health. Journal of Health Psychology. 2(4), 367-391

Watson, P.J., JrHood, R.W., \& Morris, R.J. (1990). Intrinsicness, selfActualization, and the ideological surround. Journal of Psychology and Theology. 18(1), 40-53.

Wilcox, L. (2007). Psichosufi: terapi psikologi sufistik pemberdayaan diri. Jakarta: Pustaka Cendekiamuda.

World Health Organization. (2006). Economic aspects of the mental health system: Key Messages to Health Planners and Policy Makers. Geneva: WHO Press.
World Health Organization. (2003). Investing in mental Health. Geneva: Department of Mental Health and Substance Dependence, Noncommunicable Diseases and Mental Health, World Health Organization

World Health Organization. (2004). Promoting mental health: Concepts, emerging Evidence, practice: summary report / a report from the World Health Organization. Geneva: Department of Mental Health and Substance Abuse in collaboration with the Victorian Health Promotion Foundation VicHealth and the University of Melbourne. 